\title{
AMINO-ACIDURIA IN COOLEY AND SICKLE CELL ANAEMIAS
}

\author{
BY \\ C. CHOREMIS, L. ZANNOS, AND B. BASTI \\ Athens
}

(RECEIVED FOR PUBLICATION OCTOBER, 1956)

Previous studies in this clinic and elsewhere have shown that a disturbance of serum proteins is frequently to be found in Cooley's and sickle cell anaemia, and is indicated by positive flocculation and turbidity tests. As a rule, the older the patient or the more severe the disease, the more probable it is to find the above tests positive (Allamanis, 1955).

A more detailed study of serum proteins in these anaemias by electrophoresis has shown $\gamma$-hyperglobulinaemia, which was more marked in the older children and the severe cases. The view could be upheld that the electrophoretic changes are secondary, resulting from cirrhotic changes in the liver, which, as reported in the literature, are inevitable if the patients live long enough. However, their occurrence in infants and young children in whom cirrhotic changes are not yet to be expected argues against this hypothesis.

The above observations stimulated us to investigate another aspect of pretein metabolism in these anaemias, namely, the amino-acids in blood serum and their excretion in the urine. As far as we have been able to find out from the available literature, no study of this kind has been published so far in Cooley's and sickle cell anaemia. A few reports have appeared, however, dealing with aminoaciduria in other types of anaemia. Soushon and Gruneau (1955) published one case of congenital spherocytic anaemia and cholelithiasis with aminoaciduria which was considered to be due both to liver damage and to faulty reabsorption by the tubules (Soushon and Gruneau, 1952). Weaver and Neill (1954) reported five cases of pernicious anaemia with abnormal excretion of taurine and some overexcretion of lysine, leucine, and cystine. This type of amino-aciduria was attributed to lack of vitamin $B_{12}$ which is known to be involved in methyl synthesis and transmethylation of certain amino-acids. The same authors also reported five cases of other varieties of anaemia without any pathological findings (Weaver and Neill, 1954).
Pare and Sandler (1954) described 12 cases of March haemoglobinuria with amino-aciduria.

In the above cases the renal tubular defect was considered to be the cause of the abnormal aminoaciduria (over-excretion of cystine in all cases and $\beta$-aminoisobutyric acid in 11 of the 12 cases).

\section{Material and Method}

We used the method of paper chromatography as described by Consden, Gordon, and Martin (1944) and Dent $(1947,1948)$ with a slight modification.

Whatman No. 3 filter paper was used for the blood serum and urine chromatograms, and $0.05 \mathrm{ml}$. of deproteinized serum and a volume of urine and $500 \mu \mathrm{g}$. of nitrogen.

The urine and deproteinized serum, $0.05 \mathrm{ml}$, were first treated with ammonium molybdate and nitrogen peroxide on the paper, after which two-dimensional ascending chromatography was carried out employing phenol water as the first solvent and pyridine-amyl-alcohol water as the second solvent.

Sodium cyanide and ammonium hydroxide were added to the phenol box and diethylamine to the pyridine box.

After runs the papers were dried, sprayed with a $0.1 \%$ ninhydrin solution, and dried at room temperature for 24 hours. The amino-acid spots thus developed were identified according to their position on the paper.

Their colour intensity was compared with the test spots of pure taurine.

Although two-dimensional paper chromatography is very useful for qualitative evaluation, it does not otherwise provide an accurate quantitative basis for the estimation of amino-acids, due to the varying sensitivity of the latter to ninhydrin. Phenylalanine, tyrosine, and proline have a considerably smaller ninhydrin sensitivity than glycine, valine, taurine (Dent, 1948; Bickel, Smallwood, Smellie, Baar, and Hickmans, 1952; Bickel and Hickmans, 1952; Giddey, 1953; Boulanger and Biserte, 1950; Lederer and Lederer, 1953). More accurate quantitative estimations of amino-acids by microbiological assays or chemical methods (Van Slyke) were not undertaken in the present study.

We examined 10 normal children aged 6 months to 10 years and used them as controls and 20 cases of 
Cooley's anaemia of the major type aged 6 months to 12 years with haemoglobins between 3.5 and $5 \mathrm{~g} . \%$ and a red cell count of 1.2 to 1.8 millions per c.mm.

In 15 of these patients the chromatograms were carried out during a haemolytic crisis, and in 14 cases chromatograms were repeated after the haemoglobin had been raised to 9 to $10 \mathrm{~g} . \%$ with blood transfusions.

Four of the cases had undergone splenectomy two years previously.

Ten cases of sickle cell anaemia aged 3 to 10 years, with haemoglobins of 2.5 to $5 \mathrm{~g} . \%$ and a red cell count of 1.8 to 4 millions per c.mm., were included. In five cases the chromatograms were carried out during a haemolytic crisis. In five cases the chromatograms were repeated after the haemoglobin had been raised to 9 to $10 \mathrm{~g} . \%$ with blood transfusions.

Finally, chromatograms were made of urines of two patients with acute haemolytic anaemia due to favism aged 4 and 6 years with haemoglobins of 3.5 and $4 \mathrm{~g} . \%$ and red cell counts of 1.2 to 2 millions per c.mm.; of two patients with cirrhosis and anaemia aged 6 and 7 years with haemoglobins of $6 \mathrm{~g} . \%$ and red cell counts of 2 to 4 millions per c.mm.; of two patients with Hodgkin's disease and anaemia aged 6 and 7 years with haemoglobins of $5.5 \mathrm{~g} . \%$ and red cells of 2 millions per c.mm.; of two patients with kala-azar and severe anaemia aged 4 years with a haemoglobin of $4.5 \mathrm{~g} . \%$ and red blood cells 1.5 millions per c.mm.; of one patient with congestive splenomegaly aged
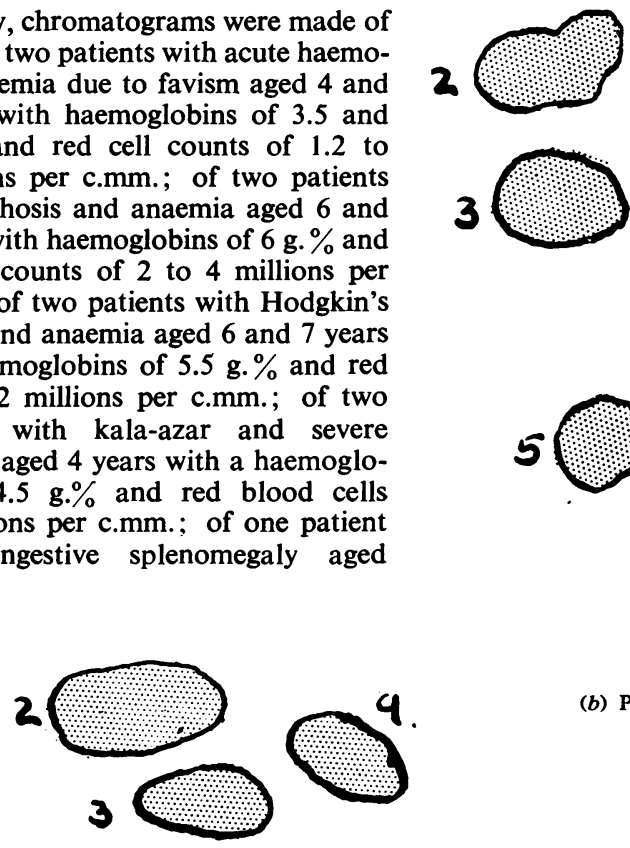

4 years with a haemoglobin of $4.5 \mathrm{~g} . \%$ and a red cell count of 2 millions per c.mm.; and of two cases of acute aplastic anaemia 10 months and 4 years without hepatosplenomegaly with a haemoglobin of $5 \mathrm{~g} . \%$ and a red cell count of 2 millions per c.mm.

\section{Results}

Control Group.-The findings for blood serum and urine(Fig. 1)in the chromatograms in the control group are in agreement with the reports in the literature of normal children.

We identified the following amino-acids:

In Serum.-Alanine, glycine, valine, glutamine, glutamic acid, tyrosine, cystine as cysteic acid, and,

(a) Physiological urine, $0.02 \mathrm{ml}$., $500 \mu \mathrm{g}$. N.
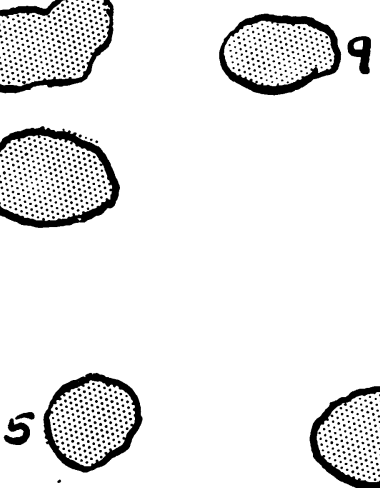

(b) Physiological blood serum, $0.05 \mathrm{ml}$.

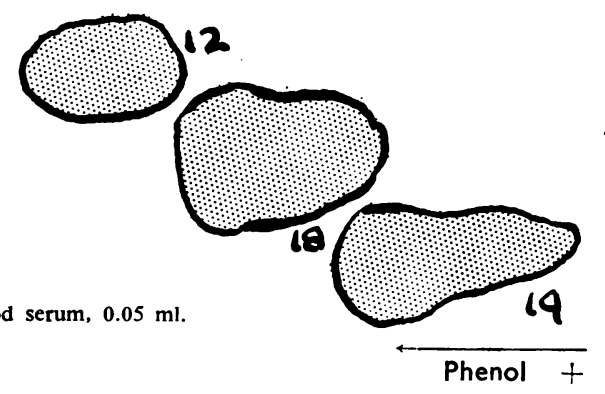

Phenylalanine $=1$

Leucine

Valine

Methionine

Histidine

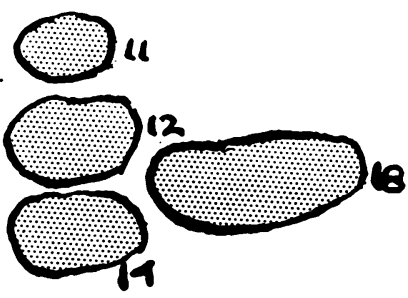

Arginine

Lysine

Tryptophane $=7$

$\begin{array}{ll}\text { Tryptophane } & =8 \\ \text { Tyrosine } & =9\end{array}$

Tyrosine
$\alpha$-Aminobutol $=9$

$\begin{array}{ll}a \text {-Aminobutol } & =10 \\ \text { Threonine } & =11\end{array}$
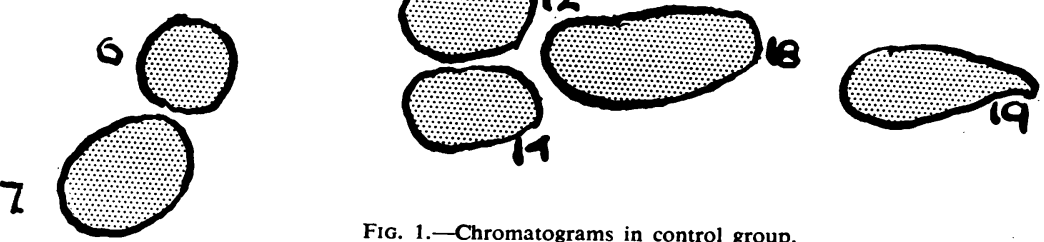

Alanine

Meoh. sulf.

Glutamine

Taurine

Serine

$=12$
$=13$

Cysteic acid $=16$

Cysteic acid $=17$

$\begin{array}{ll}\text { Glycine } & =18 \\ \text { Glutamic acid } & =19\end{array}$

Aspartic acid $=0$

FIG. 1.-Chromatograms in control group. 


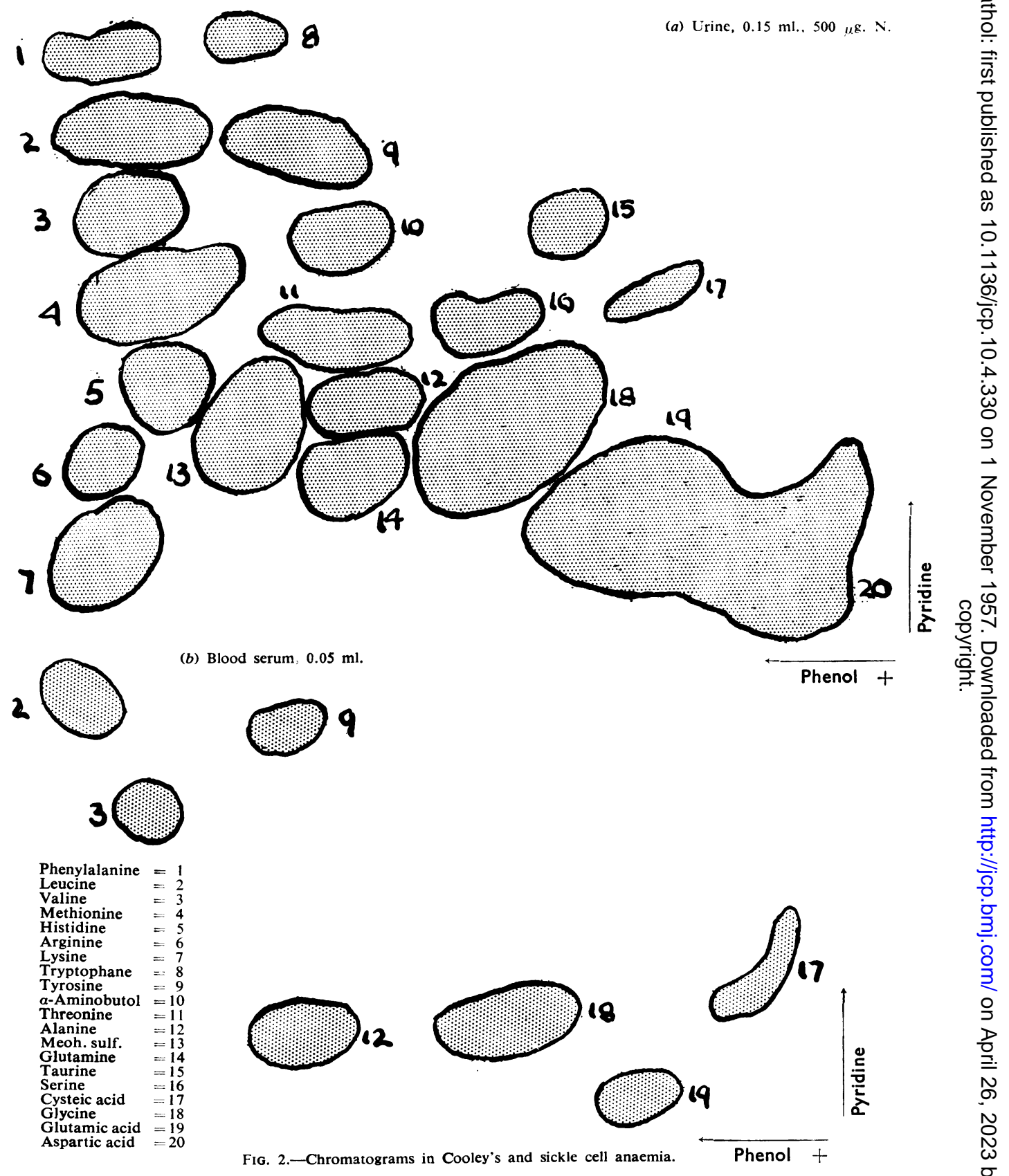

less constantly, arginine, lysine, histidine, threonine, and leucine. The colour intensity ranged between that given by 10 and $30 \mu \mathrm{g}$. of taurine.

In Urine.-Glycine, glutamic acid, alanine, cysteic acid, leucine, valine, tyrosine, threonine, histidine. The colour intensity never exceeded the colour given by $60 \mu \mathrm{g}$. taurine.
Cooley and Sickle Cell Anaemia.-Findings were similar in both Cooley and sickle cell anaemia. $\frac{\stackrel{\odot}{\Phi}}{\mathscr{D}}$ The serum amino-acids were in most of the cases $\stackrel{?}{+}$ slightly decreased in number and quantity. In no 0 case was any increase observed. On the other $\stackrel{0}{\circ}$ hand, the pattern of the urine chromatograms $\stackrel{\Phi}{\Omega}$ was distinctly abnormal in both diseases (Fig. 2). 


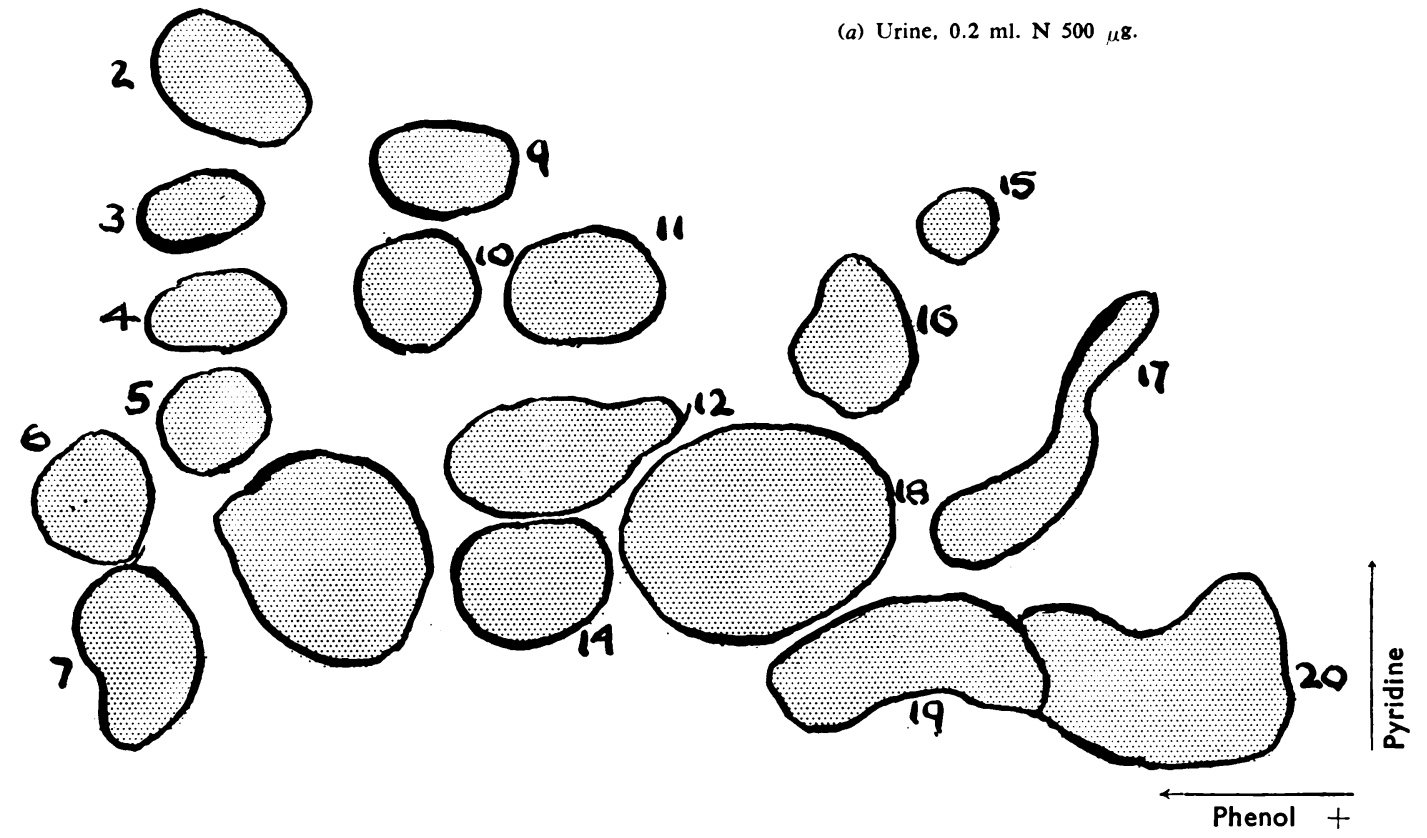

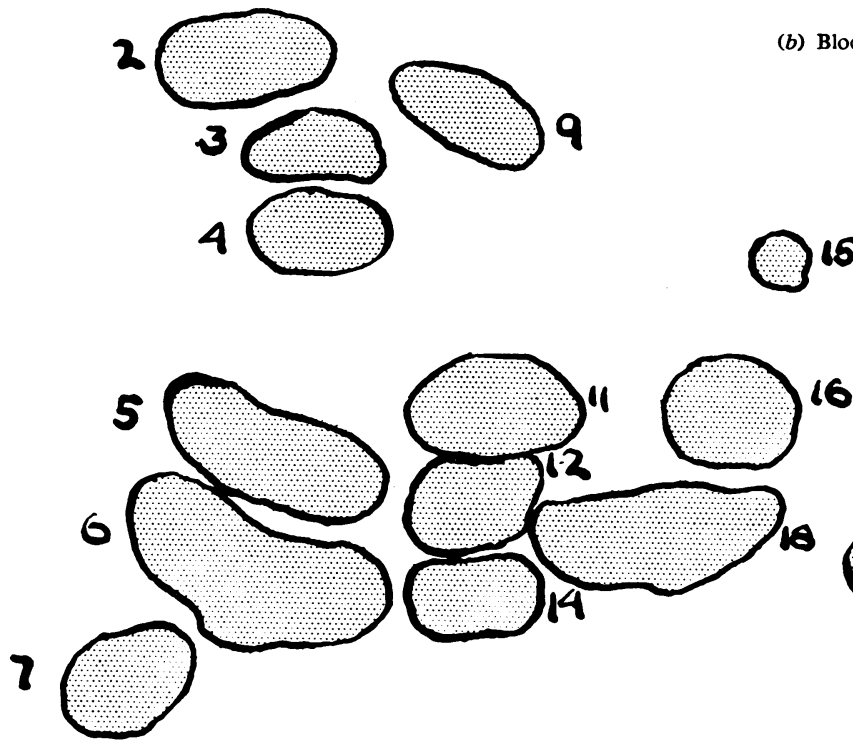

FIG. 3.-Chromatograms in cirrhosis.

As shown in Fig. 2 the number and quantity of urinary amino-acids were markedly increased, reappearing frequently, namely, glycine, glutamic acid, aspartic acid, histidine, alanine, threonine, valine, leucine, tyrosine, cysteic acid, serine, glutamine, arginine, lysine, methionine, taurine, and, less constantly, phenylalanine, tryptophane, and $\alpha$-aminoisobutyric acid. 


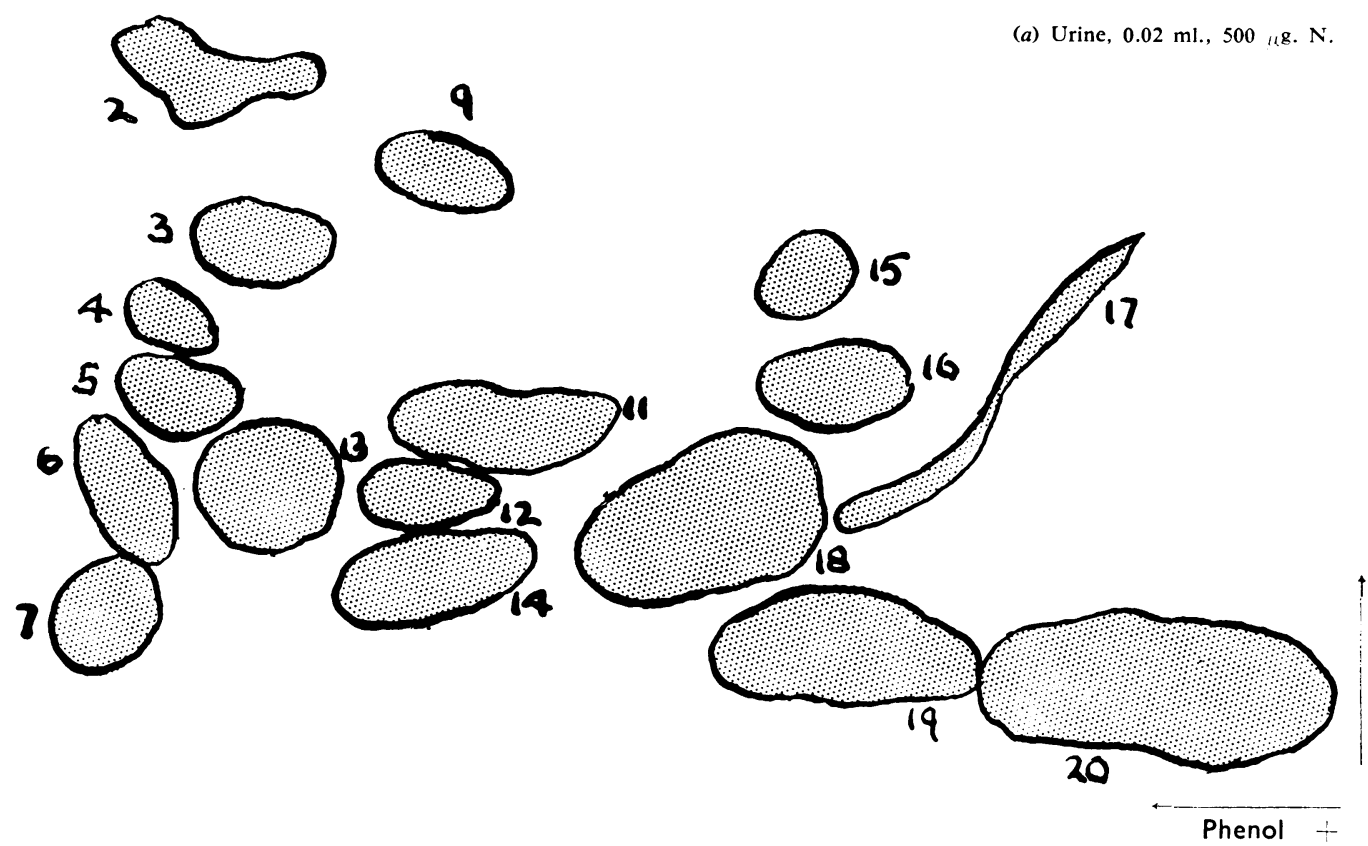

(b) Blood serum, $0.05 \mathrm{ml}$.
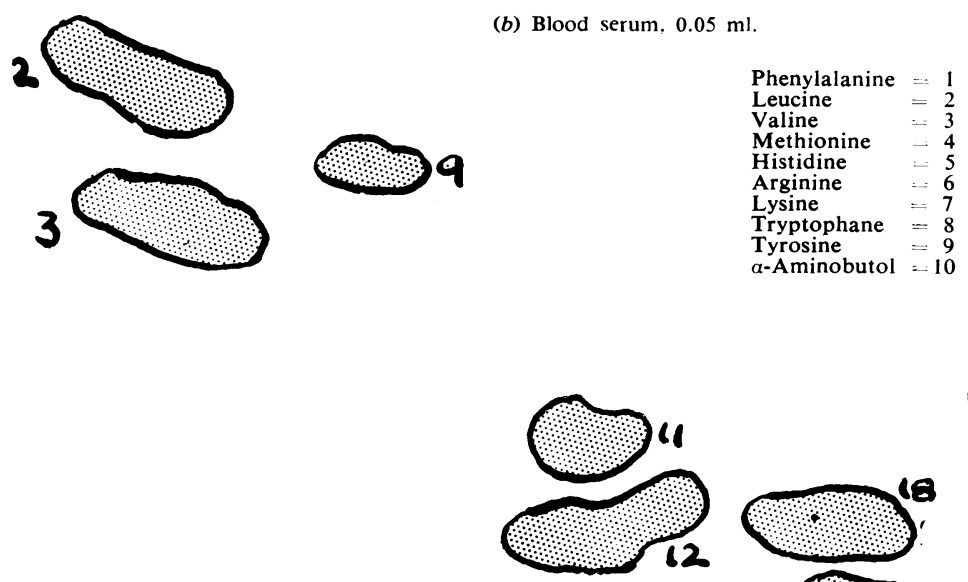

FIG. 4.-Chromatograms in acute haemolytic anaemia.

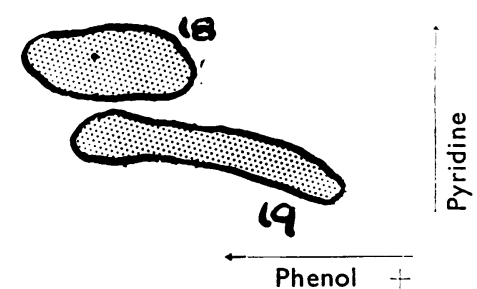

pattern of the serum and urinary chromatogram on the other.

Acute Haemolytic Anaemia.-In the two cases of acute haemolytic anaemia (favism) the findings were similar to those in Cooley and sickle cell anaemia, i.e., there is a slight decrease in the number and quantity of serum amino-acids, while the urinary amino-acids are increased (12-15 amino-acids), their colour intensity being about $100 \mu \mathrm{g}$. of taurine $\underset{\omega}{ }$ (Fig. 4). That is somewhat less than in Cooley and sickle cell anaemia. However, the number of our patients with favism is very small and no definite conclusions can be drawn.

Cirrhosis of Liver. - In those patients with cirrho- $\frac{0}{0}$ sis of the liver, kala-azar, congestive splenomegaly, $\overrightarrow{\mathbb{D}}$ and Hodgkin's disease the serum and urine chroma- $\frac{\rho}{\mathbb{P}}$ 
tograms were similar and representative of liver cirrhosis. In Fig. 3 the findings in cirrhosis can be compared to those of Cooley and sickle cell anaemia and the difference of serum amino-acids is obvious. On the other hand there is a resemblance in the pattern of urinary chromatograms.

The findings in patients with aplastic anaemia were within normal limits.

\section{Discussion}

These results indicate that amino-aciduria without hyperamino-acidaemia is a regular finding in Cooley's anaemia and sickle cell anaemia. In view of the fact that the pathogenesis is different in the two diseases and that there is no correlation between the amino-aciduria and the degree of anaemia, amino-aciduria is probably related to the chronic haemolytic process which is the only common factor. According to Dent, amino-acidurias can be classified in the following two categories (Bickel et al., 1952; Dent, 1954; Creyssel, Matray, and Loiselet, 1955; Matchaniotis, 1955): (1) Those due to an overflow of amino-acids from the blood (hyperamino-acidaemia); (2) those due to a renal tubular insufficiency (normal serum amino-acids).

Our findings (amino-aciduria without hyperamino-acidaemia) point rather to the nephrogenic origin of amino-aciduria in the two anaemias.

The exact mechanism remains to be explained.

Previous studies in our clinic and elsewhere have shown that there is an increase in the glomerular filtration rate in Cooley's and sickle cell anaemia, which has been attributed to an increase in renal circulation (renal plasma flow) due to the anaemia and to the decrease of colloid osmotic pressure (augmentation of $\gamma$-globulin and fall of albumin) (Allamanis, 1955; Papamattheaki, 1954). It is possible that the augmentation of the glomerular filtration rate explains the amino-aciduria. That hypothesis would only be acceptable if we accept that the renal tubules, due to the increased glomerular filtration rate, are forced to reabsorb amino-acids at a level above their reabsorptive capacity. If this were the case, however, correction of the anaemia by transfusions should render normal the glomerular filtration and should be followed by the disappearance of the amino-aciduria. The lower colloid osmotic pressure, which is not corrected by transfusions, may by itself be sufficient to maintain a high glomerular filtration rate.

Another possible explanation of amino-aciduria in the above anaemias is that it is due to the harmful effect of haemosiderin on the tubular epithelium. A similar hypothesis has been advanced in the explanation of amino-aciduria observed in Wilson's disease, which has been attributed to the damaging effect of copper deposits in the renal tubules (Bickel, 1955). If this were the case we should probably expect a correlation between the length of the disease and the degree of amino-aciduria, but this has not been observed.

Finally, the amino-aciduria could be congenital. This is difficult to prove since the above anaemias are rarely diagnosed in early infancy. Moreover, amino-aciduria is a common finding in normal babies at this age (Dustin, 1954).

\section{REFERENCES}

Allamanis, John (1955). Acta paediat. (Uppsala), 44, 122.

Bickel, H. (1955). Verh. dtsch. Ges. inn. Med., 61, 402.

- and Hickmans, E. M. (1952). Acta paediat. (Uppsala), 42, Suppl. 90, p. 137.

- Smallwood, W. C., Smellie, J. M., Baar, H. S., and Hickmans, E. M. (1952). Ibid., 42, Suppl. 90, p. 9.

Boulanger, P., and Biserte, G. (1950). Expos. ann. Biochim. Méd. onzième ser., p. 82. Polonovski, M. (ed.)

Creyssel, R., Matray, F., and Loiselet, J. (1955). Pédiatrie, 10, 177.

Consden, R., Gordon, A. H., and Martin, A. J. P. (1944). Biochem. J., 38, 224.

Dent, C. E. (1947). Ibid., 41, 240.

- (1948). Ibid., 43, 169.

- (1954). Exp. Med. Surg., 12, 229.

Dustin, J. P. (1954). Ibid., 12, 233.

Giddey, C. (1953). Schweiz. med. Wschr., 83, 331.

Lederer, E., and Lederer, M. (1953). Chromatography, p. 74. Elsevier Publishing Co., Amsterdam.

Matchaniotis, E. (1955). Ann. Clin. Paediat. Univ. Atheniensis, p. 171. Papamattheaki, E. (1954). The Renal Function of the Chronic Haemolytic Anaemias. Thesis for doctorate.

Pare, C. M. B., and Sandler, M. (1954). Lancet, 1, 702.

Soushon, F., and Gruneau, O. (1955). Ann. Clin. Paediat. Univ. Atheniensis, p. 171.

Weaver, J. A., and Neill, D. W. (1954). Lancet, 1, 1212. 